\title{
DOES EU TRADE INTEGRATION SUPPORT EXPORT PROMOTION: PROBIT ANALYSIS, EVIDENCE FROM KOSOVO
}

\author{
Gazmend Qorraj * \\ Gezim Jusufi**
}

\begin{abstract}
This article aims to explore European Union (EU) trade opportunities in the context of regional integration for Kosovo. Although the EU plays a role in investment promotion, monitoring, and settlement of trade disputes, there is a dilemma about benefits from EU trade openness for the countries of the region. According to the Infant Industry approach, there is a trade-off between European integration and benefits from free trade agreements in countries such as Kosovo, taking into consideration the unfavorable position of local firms due to political challenges and the long transition period for this country. This article aims to estimate whether trade integration is a significant condition for the export performance of firms or if, on the contrary, firm performance has a strong impact on export performance. We explore the link between firm characteristics and market integration by analyzing two different groups of firms, exporting and non-exporting firms, and their access to the EU market. Therefore, the core research questions of the paper are a) is the external financing a significant factor to support the firms' export; b) Did technological process and improvement of production capabilities of the firms enables export promotion; c) Did the level of education respectively human resources of the firms could have a positive impact on export growth. Based on Probit model analyses, the main conclusions are as follows: exporting firms obtained external funding, which they invested in production capacity, and non-exporting firms used their own limited financial resources. Of note is that for both groups, education level does not matter in that it does not increase the probability of firms accessing the EU market.
\end{abstract}

KEYWORDS: Trade; Regional integration; Export; Firms; Transition; Kosovo

* Gazmend Qorraj, University of Prishtina, Pristhina, Kosovo; gazmend.qorraj@uni-pr.edu.

** Gezim Jusufi, University of Prishtina, Pristhina, Kosovo; gezimi.gjilan@gmail.com. 


\section{INTRODUCTION}

Regional trade is perceived as a significant framework for economic integration, by promoting European Union (EU) trade standards, eliminating trade disputes, overcoming economic obstacles, and also creating a common market in the Western Balkans. Despite these opportunities, local firms face additional challenges such as non-tariff barriers and other technical obstacles arising from economic and political regional challenges. The EU signed the Stabilization and Association Agreement (SAA) with Kosovo, which was considered to be a good opportunity for local firms because it allowed for free access to the EU market. According to previous studies, the SAA framework could, in the short run, help countries and local firms accelerate reforms and improve technical conditions, following EU standards, which would then make them capable of accessing the EU market in the long run. ${ }^{1}$ In addition, in this paper, we test the following hypotheses:

- A firm that possesses external financial support from loans or EU funds is more likely to access the EU market.

- Firms which improve internal capabilities, such as new technologies and production, are more likely to export to the EU market.

- The level of education of firms' human resources can increase the export capabilities of the firm.

Following the study, we attempt to explore the impact of EU trade openness for Kosovo, by using the firm's approach analysis. To analyze the main components of exporting and non-exporting firms, a probit model was used to compare the characteristics of both groups of firms. Innovation in this paper is the use of a dynamic approach to update, on an annual basis, the access of local firms to the EU market. The main factors analyzed are as follows: the sources of finance for the firms, investment in new technologies, education level of their human resources, partnership with EU firms, and other variables. This is in contrast to studies by Bernard and Jensen, ${ }^{23}$ which mainly analyzed productivity and wages concerning export activities.

\footnotetext{
1 Qorraj, G.; Jusufi, G.: The EU Stabilization and Association Agreement for the Western Balkans: challenges and opportunities, Croatian International Relations Review, 24 (81) 2018, p. 52 .

2 Bernard, A.B.; Jensen, J.B.: Exporters, Jobs, and Wages in US Manufacturing: 1976-87, Brookings Papers on Economic Activity. Microeconomics, 1995, p. 67-119.

3 Bernard, A.B.; Jensen, J.B.; Exceptional exporter performance: cause, effect, or both?, Journal of International Economics, 47 (1) 1999, p. 1-25.
} 
The paper is structured as follows: introduction, theoretical background, and model and empirical research, followed by main findings and final conclusions.

\section{THEORETICAL BACKGROUND}

Trade liberalization issues have long attracted the attention of researchers. Authors such as Findlay and Wellisz, ${ }^{4}$ Brock and Magee, ${ }^{5}$ Hillman, ${ }^{6}$ and Mayer and Riezman ${ }^{7}$ identified some of the main determinants of trade policy. One approach is the "'median-voter approach", which is based on the idea that trade policy is created by the government, based on the influence of the majority of voters. The other approach is the "Interest group approach", in which trade policy reflects the interaction between the government and lobbying groups supporting the interests of their members. Other studies on trade policy were conducted by Helpman ${ }^{8}$, Krishna and Mitra, ${ }^{9}$ and Wagner ${ }^{10}$. Bernard and Wagner ${ }^{11}$ analyzed the correlation between firms' characteristics and international trade by exploring the productivity of exporting and non-exporting firms and were followed by Melitz, ${ }^{12}$ who analyzed the international activities of heterogeneous firms. Research conducted by Bernard and Jensen ${ }^{13}$ was the first to consider microeconomic data in respect to differences between export-

4 Findlay, R.; Wellisz, S.: Endogenous Tariffs and the Political Economy of Trade Restrictions and Welfare, Jagdish Bhagwati (Ed.). Import Competition and Response, IL: University of Chicago, 1982, p. 223-244.

5 Brock, W.P.; Magee, S.P.; The Economics of Special Interest Politics: The Case of Tariffs, American Economic Review, 68, 1978, p. 246-50.

6 Hillman, A.: Protection, Politics and Market Structure, International Trade and Trade Policy. Cambridge, MA: MIT Press, 1991, p. 141-145.

7 Mayer, W.; Riezman, R.: Voter Preferences for Trade Policy Instruments, Economics and Politics 2 (3) 1984, p. 259-273.

8 Helpman, E.: Politics and Trade Policy. Kreps, D.M., Wallis, K.F. (Eds.). Advances in economics and econometrics: Theory and applications, Cambridge, U.K.: Cambridge University Press, 2, 1995, p. 222-235.

9 Krishna, P.; Mitra, D.: Reciprocated Unilateralism: A Political Economy Approach. Brown University Manuscript, 2000, p. 29.

10 Wagner, J.: Exports and Productivity: A Survey of the Evidence from Firm-level Data. World Economy, 30 (1) 2007, p. 60-82.

11 Bernard, A.B.; Wagner, J.: Exports and Success in German Manufacturing, Weltwirtschaftliches Archive, 133 (1) 1997, p. 134-157.

12 Melitz, M.: The Impact of Trade on Intra-Industry Reallocations and Aggregate Industry Productivity, Econometrica, 71 (6) 2003, p. 1695-1725.

13 Bernard, A.B.; Jensen, J.B.: Exporters, Jobs, and Wages in US Manufacturing: 1976-87, Brookings Papers on Economic Activity. Microeconomics, 1995, p. 67-119. 
ing and non-exporting firms. Furthermore, entrepreneurs' characteristics were considered when analyzing trade effects by Qorraj and Jusufi ${ }^{14}$ respectively necessity and opportunity entrepreneurs.

The empirical evidence of Irwin ${ }^{15}$ finds that a country's trade reforms, in particular, the reduction of import tariffs have a positive impact on economic growth. But this result does not apply to all countries. Overall, the research verifies the empirical link between trade reform and a country's economic performance. In addition, according to Rose Malefane, ${ }^{16}$ a country's total trade and exports must be increased through specific and well-structured policies. But the state needs to review the structure of imports to enable significant growth effects of the national economy from the import sector.

Furthermore, Adegboye et al. ${ }^{17}$ claim that trade liberalization has a negligible impact on economic development for developing countries. To benefit from trade liberalization, the countries should fulfill many preconditions and the level and responsibility of inter-regional trade must be increased. Also, income growth, better education, improved life expectancy, a suitable economic environment must be provided in advance by these countries in order to have positive effects of trade liberalization on the national economy. Additionally, Vo and Nguyen ${ }^{18}$ provide empirical evidence that trade liberalization improves household incomes and expenditures in developing countries because it creates export channels and expands labor demand.

\footnotetext{
14 Qorraj, G.; Jusufi, G.: EU vs. Local Market Orientation: Western Balkan Entrepreneurs' Challenge, EBER- Entrepreneurial Business and Economics Review, 7 (4) 2019, p. 21-32.

15 Irwin, A.D: Does Trade Reform Promote Economic Growth?, A Review of Recent Evidence. (PIIE) Peterson Institute for the International Economics, Washington D.C. USA, 2019, p. 54. https://www.piie.com/system/files/documents/wp19-9.pdf

16 Rose Malefane, M.: Trade openness and economic growth in Botswana: Evidence from cointegration and error-correction modeling, Cogent Economics \& Finance, 8 (1) 2020, p. 46. https://www.tandfonline.com/doi/pdf/10.1080/23322039.2020.1783878?needAccess=true

17 Adegboye, F.B., Matthew, A. O., Ejemeyovwi, J., Adesina, S.O. and Osabohien, R.: Assessing the Role of Trade Liberalization in Facilitating Trade Flows and Economic Expansion: Evidence from ECOWAS Countries, Fostering Trade in Africa, 2020, p.1-211. https:// link.springer.com/chapter/10.1007/978-3-030-36632-2_5

18 Vo, T.T.; Nguyen, D.X.: Impact of Trade Liberalization on Household Welfare: An Analysis Using Household Exposure-to-Trade Indices, Social Indicators Research, 153, 2021, pp. 503 531. https://link.springer.com/article/10.1007/s11205-020-02499-1\#citeas
} 
However, unlike other research, the research of Roy-Mukherjee and Udeogu ${ }^{19}$ states that institutional quality is a very important factor that determines the positive effects of trade liberalization, especially in the Western Balkans. The improvement in institutional quality the greater will be the positive effects of trade liberalization for the country. According to Giordano and Lopez-Gar$\mathrm{cia}^{20}$ trade openness increases the productivity of individual firms, through a number of channels, and also increases allocation efficiency between firms. This increases overall productivity at the national level. Wagner ${ }^{21}$ claims that distance to destination countries affects the level of exports of exporting firms, as well as changes in economic size and per capita income of countries where exporting firms are located, ease of conducting international trade with different countries affect the level of exports of these firms. Raimondi et al. ${ }^{22}$ report that geographical indicators of the country affect trade flows in both exports and imports. The presence of these indications in the exporting country has a positive trade effect on both broad and intensive trade margins. When registered only in the importing country, these indications appear to act poorly as a measure of trade reduction, at least in the intensive trade margin.

Meanwhile, according to Jusufi et al. ${ }^{23}$, Kosovo exporting firms need to support innovations to increase their exports. Empirical evidence provides data that innovative products are more appropriate and useful for increasing the export capacity of these firms. Managers of exporting firms must increase the quality of their products through the application of EU quality standards. Certification by modern standards requires greater commitment and adequate hu-

19 Roy-Mukherjee.; Sh., Udeogu, E.: Neo-liberal Globalization and Income Inequality: Panel Data Evidence from OECD and Western Balkan Countries, Journal of Balkan and Near Eastern Studies, 23 (1) 2021, p. 65. https://www.tandfonline.com/doi/citedby/10.1080/ 19448953.2020.1852004?

20 Giordano, C.; Lopez-Garcia, P.: Firm heterogeneity and international trade: A cross-country analysis within the EU. The Journal of International Trade \& Economic Development, 30 (1) 2021, p. 68-103. https://ideas.repec.org/a/taf/jitecd/v30y2021ilp68-103.html

21 Wagner, J.: Chapter 24: Export Scope and Characteristics of Destination Countries: Evidence from German Transaction Data, Micro econometric Studies of Firms' Imports and Exports, 2021, p. 445-451. https://www.worldscientific.com/doi/10.1142/9781786349699_0025

22 Raimondi, V., Falco, Ch., Curzi, D. and Olper, A.: Trade effects of geographical indication policy: The EU case, Journal of Agricultural Economics, 71 (2) 2020, p. 330-356. https://ideas. repec.org/a/bla/jageco/v71y2020i2p330-356.html

23 Jusufi, G., Ukaj, F. and Ajdarpašić, S.: The Effect of Product Innovation on the Export Performance of Kosovo SMEs, Management: Journal of Contemporary Management Issues. 25, (2) 2020, p. 220. https://hrcak.srce.hr/index.php?show=clanak\&id_clanak_jezik=360019 
man and financial resources, results which have been confirmed and achieved also by Patnaik ${ }^{24}$.

Following the paper, there is evidence of the trade relations between Kosovo and countries of the region as well as with the EU. The EU trade policy for the region is a conditional instrument for these countries to continue with other EU policies regarding stages of the European Integration. Most of the governments and political leaders have tried to promote an open market with the EU as an opportunity for local firms, without conducting the cost-benefit analysis. In addition to regional free trade agreements such as CEFTA 2006, signed in 2006, Western Balkan countries signed the Stabilisation and Association Agreement as part of the Stabilisation and Association Process with the European Union. Tables 1 and 2 show the trade patterns of Kosovo with Western Balkan countries and trade relations with the European Union.

Table 1: Kosovo's export share to countries in the Western Balkans region (\%).

\begin{tabular}{|l|r|r|r|r|r|r|r|r|r|}
\hline \multicolumn{1}{|c|}{ Country } & $\mathbf{2 0 1 2}$ & $\mathbf{2 0 1 3}$ & $\mathbf{2 0 1 4}$ & $\mathbf{2 0 1 5}$ & $\mathbf{2 0 1 6}$ & $\mathbf{2 0 1 7}$ & $\mathbf{2 0 1 8}$ & $\mathbf{2 0 1 9}$ & $\mathbf{2 0 2 0}$ \\
\hline Albania & 14.6 & 14.6 & 14.9 & 13.3 & 16.8 & 17.7 & 18.6 & 17.6 & 23.2 \\
\hline North Macedonia & 9.6 & 8.9 & 10.0 & 9.1 & 15.5 & 9.6 & 11.9 & 11.5 & 9.3 \\
\hline Montenegro & 6.1 & 5.9 & 5.2 & 1.5 & 4.4 & 5.5 & 5.3 & 5.1 & 3.9 \\
\hline Serbia & 5.4 & 4.9 & 4.6 & 10.7 & 9.1 & 5.5 & 9.1 & 7.1 & 6.4 \\
\hline BIH & 0.7 & 1.0 & 0.8 & 0.8 & 3.1 & 2.2 & 2.3 & 1.7 & 1.5 \\
\hline Countries total & 36.4 & 35.3 & 35.5 & 35.4 & 48.9 & 39.9 & 47.2 & 43.0 & 44.3 \\
\hline
\end{tabular}

Source: Kosovo Agency of Statistics, External Trade Statistics (2021)

According to table 2, Kosovo's main regional partners for the export of goods are Albania (23.2\%) and North Macedonia (9.3\%), as seen in Table 1. Political problems have led Kosovo's exports to Serbia and Bosnia and Herzegovina to be less than to other regional countries. Kosovo has also faced a blockade of its exports by these countries. The political climate defines the export of Kosovo to regional countries.

Following the paper, we will report on the export pattern between Kosovo and the EU. With regard to Kosovo exports to the EU (Table 2), the main Kosovo partners are Germany (9.3\%), Italy (6.0), and Netherlands (4.6\%).

\footnotetext{
24 Patnaik, S.: Emissions permit allocation and strategic firm behavior: Evidence from the oil sector in the European Union emissions trading scheme, Business Strategy and the Environment, 29 (3) 2020,p.976-995. https://ideas.repec.org/a/bla/bstrat/v29y2020i3p976-995.html
} 
Table 2: Kosovo's export share to the EU.

\begin{tabular}{|l|c|c|c|c|c|c|c|c|c|}
\hline \multicolumn{1}{|c|}{ Country } & $\mathbf{2 0 1 2}$ & $\mathbf{2 0 1 3}$ & $\mathbf{2 0 1 4}$ & $\mathbf{2 0 1 5}$ & $\mathbf{2 0 1 6}$ & $\mathbf{2 0 1 7}$ & $\mathbf{2 0 1 8}$ & $\mathbf{2 0 1 9}$ & $\mathbf{2 0 2 0}$ \\
\hline Austria & 1.6 & 2.2 & 1.8 & 1.0 & 1.8 & 0.6 & 2.3 & 2.2 & 1.5 \\
\hline Belgium & 0.2 & 0.3 & 0.3 & 2.0 & 0.3 & 0.3 & 0.7 & 1.2 & 1.7 \\
\hline Great Britain & 0.8 & 0.7 & 0.2 & 0.1 & 0.6 & 3.6 & 2.7 & 2.9 & 3.1 \\
\hline Denmark & 0.1 & 0.0 & 0.1 & 0.0 & 0.0 & 0.2 & 0.6 & 1.1 & 0.2 \\
\hline France & 0.7 & 0.5 & 0.4 & 0.3 & 0.4 & 1.2 & 0.9 & 1.1 & 1.6 \\
\hline Germany & 5.4 & 3.7 & 3.2 & 4.4 & 4.1 & 6.2 & 6.8 & 8.1 & 9.3 \\
\hline Greece & 0.1 & 0.3 & 0.2 & 0.4 & 0.4 & 0.4 & 0.4 & 0.4 & 0.3 \\
\hline Netherlands & 0.5 & 0.8 & 0.5 & 2.7 & 3.8 & 3.9 & 4.0 & 4.3 & 4.6 \\
\hline Hungary & 0.0 & 0.1 & 0.0 & 0.0 & 0.1 & 0.2 & 0.2 & 0.4 & 0.6 \\
\hline Ireland & 0.0 & 0.0 & 0.0 & 0.0 & 0.0 & 0.1 & 0.0 & 0.0 & 0.0 \\
\hline Italy & 2.5 & 2.3 & 1.2 & 0.8 & 1.2 & 1.2 & 2.1 & 5.9 & 6.0 \\
\hline Luxembourg & 0.0 & 0.0 & 0.1 & 0.1 & 1.0 & 0.0 & 0.1 & 0.1 & 0.1 \\
\hline Poland & 0.3 & 1.3 & 1.6 & 0.4 & 1.0 & 1.2 & 1.4 & 1.3 & 1.1 \\
\hline Czech Republic & 0.2 & 0.2 & 0.2 & 0.0 & 0.3 & 0.1 & 0.2 & 0.6 & 0.5 \\
\hline Slovakia & 1.1 & 0.7 & 0.0 & 0.2 & 0.1 & 1.0 & 0.0 & 0.1 & 0.0 \\
\hline Slovenia & 0.5 & 0.5 & 0.2 & 0.2 & 0.4 & 0.2 & 3.7 & 1.8 & 0.8 \\
\hline Spain & 0.2 & 0.1 & 0.1 & 1.3 & 0.2 & 0.0 & 0.1 & 0.2 & 0.1 \\
\hline Sweden & 0.1 & 0.2 & 0.2 & 0.7 & 0.4 & 0.4 & 0.5 & 0.8 & 1.9 \\
\hline Romania & 0.5 & 0.2 & 0.2 & 0.4 & 0.1 & 0.4 & 0.5 & 0.4 & 0.5 \\
\hline Bulgaria & 0.7 & 0.3 & 2.0 & 3.7 & 3.3 & 2.7 & 2.0 & 1.4 & 1.5 \\
\hline Croatia & 0.9 & 0.9 & 1.0 & 1.2 & 0.9 & 0.2 & 0.8 & 0.9 & 0.9 \\
\hline Other EU & 0.1 & 2.0 & 0.1 & 0.2 & 0.1 & 0.1 & 0.1 & 1.1 & 1.2 \\
\hline 28 EU countries & 16.5 & 17.3 & 13.6 & 20.1 & 20.5 & 24.2 & 30.1 & 36.3 & 37.5 \\
\hline
\end{tabular}

Source: Kosovo Agency of Statistics, International Trade Statistics (2021)

Comparing the percentage of exports in 2020 with the percentage in previous years, there is a slight increase in Kosovo's exports to the EU. As the SAA came into effect in 2016, there is a need to analyze continuously if the increase in exports is the result of the agreement, or due to other variables.

\section{THE MODEL AND EMPIRICAL RESULTS}

In our work, we have analyzed two types of firms in Kosovo: exporting and non-exporting firms. The aim of selecting firms in two groups was to evaluate the effect of SAA on exporting trends and to analyze the barriers which prevent non-exporting firms from exporting. By using a probit model in SPSS Statistics and descriptive statistics, we were able to analyze the main factors 
affecting the ability of firms to access the EU market, while considering challenges and the specific business environment in the region. The data used were from surveys we conducted between January 2018 and the beginning of March 2018. Two hundred local firms were included, 100 exporting and 100 non-exporting firms. Additionally, we selected data on firms from the National Customs Agency, for exporting and non-exporting firms.

Due to a limited number of exporting firms, we could not select firms based on any specific sector. We surveyed firms in the seven regions of Kosovo. We surveyed exporting firms in Prishtina (36\%), Gjilani (19\%), Ferizaj (18\%), Prizren (10\%), Peja (9\%), Gjakova (5\%), and Mitrovica (3\%). Non-exporting firms were surveyed in Prishtina (42\%), Gjilan (26\%), Ferizaj (10\%), Prizren (2\%), Peja (12\%), Gjakova (5\%), and Mitrovica (3\%). Firms were randomly chosen from the above-mentioned Kosovo main cities. The questionnaire consisted of 10 questions, which are our model variables. The survey was designed as a simple questionnaire, to avoid complexities such as personal questions and questions related to their financial and tax issues, in order to address the main issues under consideration, and obtain accurate data for the purpose of the study. The formulation of the questionnaire ensured also a higher rate of response as the questionnaire structure comprises three parts such as first part basic data of the firms e.g. year of registration, ownership, activity, etc.; the second part contains information regarding exporting activities, barriers to the export of the firms, etc., while the third part include the impact of SAA, production capabilities, human resources and other relevant variables which affects the export promotion.

The econometric model of the paper which measures the export growth is as follows:

$$
\mathrm{y}=\beta_{1}+\beta_{2} \mathrm{X}_{1}+\beta_{3} \mathrm{X}_{2}+\beta_{4} \mathrm{X}_{3}+\beta_{5} \mathrm{X}_{4}+\mathrm{q}
$$

$\mathrm{y}=$ Export growth, $\beta_{1}=$ Regression coefficient, $\mathrm{X}_{1}=$ Transaction costs, $\mathrm{X}_{2}=$ Human resources, $\mathrm{X}_{3}=$ Production capacities, $\mathrm{X}_{4}=$ Financial assets, $\mathrm{q}=$ Error term.

In Table 3, we present the descriptive statistics of variables that are used in our model and empirical research. We also present the differences in means between exporting and non-exporting firms, by measuring their statistical significance. The significance of the differences in means, estimated, provided useful information on comparative issues between the two populations. 
Table 3: Comparison of characteristics between exporting firms and non-exporting firms-mean

\begin{tabular}{|c|c|c|c|c|}
\hline Variables & $\begin{array}{l}\text { Ex- } \\
\text { porting } \\
\text { firms }\end{array}$ & $\begin{array}{l}\text { Non-ex- } \\
\text { porting } \\
\text { firms }\end{array}$ & $\begin{array}{l}\text { p-value test } \\
\text { for difference } \\
\text { in means } \\
\end{array}$ & $\begin{array}{l}\text { Signifi- } \\
\text { cance of } \\
\text { difference }\end{array}$ \\
\hline Number of observations & 100 & 100 & & \\
\hline $\begin{array}{l}\text { Informed about SAA } \\
(\% ; \mathrm{Yes}=1, \mathrm{No}=2)\end{array}$ & 91 & 16 & 0.000 & $* * *$ \\
\hline $\begin{array}{l}\text { The start of export since SAA } \\
\text { implementation } \\
(\% ; \mathrm{Yes}=1, \mathrm{No}=2)\end{array}$ & 29 & 0 & 0.000 & $* * *$ \\
\hline $\begin{array}{l}\text { Expectations of the SAA } \\
(\% ; \text { Positive }=1, \text { Negative }=2)\end{array}$ & 99 & 90 & 0.011 & \\
\hline $\begin{array}{l}\text { Recent investments in } \\
\text { production capacities } \\
(\% ; \text { Yes }=1, \mathrm{No}=2)\end{array}$ & 95 & 68 & 0.000 & $* * *$ \\
\hline $\begin{array}{l}\text { If there is investment, } \\
\text { what is the source } \\
(\% \text {; Own resources=1, Credit=2) }\end{array}$ & 34 & 57 & 0.014 & $* * *$ \\
\hline $\begin{array}{l}\text { Receipt of funds from IPA } \\
\left(\% ; \text { Yes }=1, \mathrm{No}_{2}\right)\end{array}$ & 40 & 1 & 0.000 & $* * *$ \\
\hline $\begin{array}{l}\text { Human resources } \\
(\% ; \text { Higher education }=1, \text { Average } \\
\text { education }=2, \text { Low education }=3)\end{array}$ & 30 & 34 & 0.578 & \\
\hline $\begin{array}{l}\text { Reduced transaction costs as a } \\
\text { result of SAA }(\% \text {; Yes }=1, \mathrm{No}=2)\end{array}$ & 31 & 2 & 0.000 & $* * *$ \\
\hline $\begin{array}{l}\text { Cooperation with EU firms } \\
(\% ; \text { Yes }=1, \mathrm{No}=2)\end{array}$ & 45 & 4 & 0.000 & $* * *$ \\
\hline $\begin{array}{l}\text { Is free movement a barrier to EU } \\
\text { exports }(\% ; \text { Yes }=1, \mathrm{No}=2)\end{array}$ & 71 & 93 & 0.000 & $* * *$ \\
\hline
\end{tabular}

Notes: $* * *=$ significant at $\mathrm{p}<0.01$.

Source: Questionnaire and calculations, Authors' own work (2018)

From Table 3, it is evident that $91.5 \%$ of the exporting firms are informed about SAA, while only $16 \%$ of non-exporting firms are informed about it. To check if the firms benefited from the SAA, we have asked if they have had exported before the implementation of the SAA or after the implementation. Only 29\% of exporting firms have started exporting to the European Union since the SAA went into effect, whereas $71 \%$ of exporting firms exported to the EU before the SAA. Expectations about SAA seem to be relatively high, as almost 99\% of the exporting firms declared that they expect positive effects from the 
Stabilization and Association Agreement. Similarly, non-exporting firms have expected a positive impact from the SAA; around 90\% of those firms reported positive expectations.

Interestingly, $95 \%$ of the exporting firms have invested in production capacities recently, while $68 \%$ of non-exporting firms have invested. This is an indication that exporting firms have invested in production capacities to increase their competitive capabilities in both the domestic and European markets. In Table 3 , another very interesting trend emerges: $34 \%$ of the exporting firms reported investing their own resources, while the other source of investments was bank loans. Around $57 \%$ of non-exporting firms declared that the source of the investments was their own resources, while the rest reported using bank loans. These results suggest that non-exporting firms have been relying on their own resources and thus could not increase their exports and growth compared to the exporting firms, which used external funds to increase their capabilities and consequent export performance.

We compared exporting and non-exporting firms on receiving funds from Instrument for Pre-accession Assistance (IPA). Only 40\% of exporting firms and $1 \%$ of non-exporting firms reported received funds from IPA. It is expected that funding in this period is crucial for all firms, whether exporters or non-exporters and that they should, therefore, work harder to obtain these funds from the EU. The results of the variable exploring labor market issues in Kosovo reveal that exporting firms had fewer qualified human resources compared with non-exporting firms. Exporting firms have 30\% human resources with higher education, while this segment represents $34 \%$ of human resources in non-exporting firms. Although there is not a significant difference between these figures, we can conclude that non-exporting firms have more highly educated human resources than exporting firms; therefore, in this case, it seems that the education level does not support the firms to export. Regarding the reduction of transaction costs as a result of SAA, 31\% of exporting firms reported reduced transaction costs as a result of SAA implementation, compared with only $2 \%$ of non-exporting firms. In terms of cooperation of Kosovo firms with EU firms, $45 \%$ of exporting firms but only $4 \%$ of non-exporting firms have this cooperation.

The final variable highlights the difficulty of free movement to the EU, especially for Kosovo exports. $71 \%$ of exporting firms declared that free movement is a barrier to the EU market, and $93 \%$ of non-exporting firms declared the same. From these results, we can conclude that free movement is a barrier to both types of analyzed firms.

In Table 5, we present a more detailed analysis for these firms. We first compared data on whether representatives of these firms are informed about the 
SAA. Exporting firms are more likely to be informed about the SAA than non-exporting firms. Regarding exports, exporting firms are more prepared and experienced than non-exporting firms. We can conclude, based on this probability, that exporting firms are more inclined to increase exports than firms that have not yet begun to export to the EU.

Table 5: Probit analysis of Kosovo exporting and non-exporting firms.

\begin{tabular}{|l|c|}
\hline \multicolumn{1}{|c|}{ Variables } & $\begin{array}{c}\text { Exporting firms vs. } \\
\text { Non-exporting firms }\end{array}$ \\
\hline Number of observations & $\mathbf{2 0 0}$ \\
\hline Informed about SAA & 0.394 \\
\hline The start of export since SAA implementation & $-(0.071)^{* * *}$ \\
\hline Expectations of the SAA & 0.312 \\
\hline Recent investments in production capacities & $-(0.008)^{* * *}$ \\
\hline If there is investment, what is the source & 0.288 \\
\hline Receipt of funds from IPA & $(0.271)$ \\
\hline Human resources qualifications & 0.307 \\
& $(0.296)^{* * *}$ \\
\hline Reduced transaction costs as a result of SAA & 0.227 \\
\hline Cooperation with EU firms & $(0.184)$ \\
\hline Is free movement a barrier to EU exports & 0.249 \\
& $-(0.004)^{* * *}$ \\
\hline
\end{tabular}

Notes: Coefficients are marginal effects; $* * *=$ significant at $\mathrm{p}<0.01$.

Source: Questionnaire and calculations, Authors' own work (2018)

Both groups of firms have approximately the same probability of having positive expectations about the SAA. Exporting firms have made more investments recently in production capacities than have non-exporting firms. This probability indicates that exporting firms are more likely to develop their production than are non-exporting firms, even if they do not have the power to compete with EU firms. But it also shows that even non-exporting firms are interested in production investments, which could allow for export in the future. 
Regarding investment sources, exporting firms are more likely to use credit, while non-exporting firms tend to use their own resources for investment in production capacities. Even here, there is no statistically significant difference in the probability of using the sources of investment tools between exporting and non-exporting firms. It is evident that Kosovo firms, due to the lack of their own resources, largely use various financial instruments to finance their business activities. What about receiving funds from IPA? In Table 4, we can see that exporting firms have used much more IPA funds than have non-exporting firms. Thus, the probability of using these funds is higher for exporting firms than non-exporters. IPA funds have likely filled the gap in the lack of internal resources of exporting firms because as we have seen above, these firms use less of their own resources than non-exporting firms.

Furthermore, we have presented the probability of possessing highly qualified human resources for both groups of firms analyzed. Taking into account the inadequate education system in Kosovo, we can conclude that all types of Kosovo firms lack the qualified human resources required by the market, and especially by the EU market. Exporting firms that were exporting previously, even before SAA have a higher probability of reduced transaction costs than non-exporting firms. Their experience thus far in the EU market has facilitated their activity in reducing transactional costs. Exporting firms have a higher probability than non-exporting firms of cooperation with EU firms. Non-exporting firms, even though they have invested in production capacities, have no experience of cooperation with EU firms, so they will find it harder to create cooperation with EU firms, compared with exporting firms that have experience cooperating with EU firms. Finally, we asked firms about export barriers to the EU. Free movement, for non-exporting firms, represents a major barrier to EU exports. Based on this variable, we conclude that exporting firms have a higher probability of exporting to the EU than do non-exporting firms.

\section{CONCLUSIONS}

Although there is a large debate about the positive impact of trade liberalization on less-developed economies, and specifically about infant industries such as Kosovo and other countries, the results are mixed. From the EU-perspective approach, there are significant benefits, such as advancement of technical standards of production and other terms of trade, as well as fulfillment of EU standards. From the economic point of view regarding export promotion in the case of Kosovo, there is trade diversion, due to limited access of local firms to the EU market, taking into consideration capabilities of these firms, institutional support, and other specific challenges, such as limited free movement of business people to EU countries. 
The probit model results reveal that the firms differ in their potential to use SAA opportunities in respect to the EU market. Regarding the hypotheses outlined above:

- Compared with non-exporting firms, exporting firms have more access to the EU market, as these firms possess external financial support from banking loans and EU IPA funds.

- Exporting firms, compared with non-exporting firms, improved their internal capabilities, such as new technologies and production capabilities, and thus developed their export capabilities.

- Regarding the level of education of firms' human resources, both exporting and non-exporting firms showed that education level is not significant for the firm's performance. This result could be explained by the fact that Kosovo firms are not exporting any value-added products or services; therefore, educational level is not a significant factor.

According to this study, a crucial factor for increasing exports and performance is external funding. Exporting firms are using more external financial sources, although their own capital is larger compared with non-exporting firms. This could be explained by the fact that exporting firms have better access to credit markets than Small and Medium Enterprises and, consequently, they have a higher probability of access to the EU market.

\section{RESEARCH CONTRIBUTION}

The main contribution of this research is the evaluation of trade openness relative to the impact of EU trade instruments in the Western Balkans, taking into consideration their infant industries and the eco-political challenges of the region, specifically Kosovo. Another added value is the comparison of the local firms' characteristics, to measure their capability for export to the EU market.

\section{LIMITATIONS}

One limitation of this paper is the short period of the SAA implementation in Kosovo and the resulting lack of data for different economic sectors, due to the limited number of firms exporting to the EU market. Additionally, the small sample of firms surveyed for the analysis is a challenge. 


\section{FURTHER RESEARCH}

It is possible to extend our research by monitoring export trends in the coming years and analyzing exporting firms to determine if new firms joined the EU market mainly due to trade liberalization or due to advancement of their technologies and production capabilities. Secondly, additional research could be conducted to analyze different sectors of the economy to evaluate in which sectors there are increasing exporting trends. The third follow-up would be to extend the Bernard and Jensen (1997) analysis to evaluate if current exporting firms increased their productivity due to export, e.g., "analysis of the firm performance after entry".

\section{LITERATURE}

1. Adegboye, F.B. et al.: Assessing the Role of Trade Liberalization in Facilitating Trade Flows and Economic Expansion: Evidence from ECOWAS Countries, Fostering Trade in Africa, 2020, p. 1-211. https://link.springer.com/chapter/10.1007/978-3-030-36632-2_5

- DOI: https://doi.org/10.1007/978-3-030-36632-2_5

2. Bernard, A.B.; Jensen, J.B.: Exporters, Jobs, and Wages in US Manufacturing: 1976-87, Brookings Papers on Economic Activity. Microeconomics, 1995, p. 67119.

- DOI: https://doi.org/10.2307/2534772

3. Bernard, A.B.; Wagner, J.: Exports and Success in German Manufacturing, Weltwirtschaftliches Archive, 133 (1) 1997, p. 134-157.

- DOI: https://doi.org/10.1007/BF02707680

4. Bernard, A.B.; Jensen, J.B.; Exceptional exporter performance: cause, effect, or both?, Journal of International Economics, 47 (1) 1999, p. 1-25.

- DOI: https://doi.org/10.1016/S0022-1996(98)00027-0

5. Brock, W.P.; Magee, S.P.; The Economics of Special Interest Politics: The Case of Tariffs, American Economic Review, 68, 1978, p. 246-50.

6. Findlay, R.; Wellisz, S.: Endogenous Tariffs and the Political Economy of Trade Restrictions and Welfare, Jagdish Bhagwati (Ed.). Import Competition and Response, IL: University of Chicago, 1982, p. 223-244.

7. Giordano, C.; Lopez-Garcia, P.: Firm heterogeneity and international trade: A cross-country analysis within the EU. The Journal of International Trade \& Economic Development, 30 (1) 2021, p. 68-103. https://ideas.repec.org/a/taf/jitecd/ v30y2021ilp68-103.html

- DOI: https://doi.org/10.1080/09638199.2020.1788123 
8. Helpman, E.: Politics and Trade Policy. Kreps, D.M., Wallis, K.F. (Eds.). Advances in economics and econometrics: Theory and applications, Cambridge, U.K.: Cambridge University Press, 2, 1995, p. 222-235.

9. Hillman, A.: Protection, Politics and Market Structure, International Trade and Trade Policy. Cambridge, MA: MIT Press, 1991, p. 141-145.

10. Irwin, A.D: Does Trade Reform Promote Economic Growth?, A Review of Recent Evidence. (PIIE) Peterson Institute for the International Economics, Washington D.C. USA, 2019, p. 54. https://www.piie.com/system/files/documents/wp19-9.pdf - DOI: https://doi.org/10.3386/w25927

11. Jusufi, G. et al.: The Effect of Product Innovation on the Export Performance of Kosovo SMEs, Management: Journal of Contemporary Management Issues. 25, (2) 2020, p. 220. https://hrcak.srce.hr/index.php?show=clanak\&id_clanak_ jezik=360019

- DOI: https://doi.org/10.30924/mjcmi.25.2.12

12. Krishna, P.; Mitra, D.: Reciprocated Unilateralism: A Political Economy Approach. Brown University Manuscript, 2000, p. 29.

13. Mayer, W.; Riezman, R.: Voter Preferences for Trade Policy Instruments, Economics and Politics 2 (3) 1984, p. 259-273.

- DOI: https://doi.org/10.1111/j.1468-0343.1990.tb00033.x

14. Melitz, M.: The Impact of Trade on Intra-Industry Reallocations and Aggregate Industry Productivity, Econometrica, 71 (6) 2003, p. 1695-1725.

- DOI: https://doi.org/10.1111/1468-0262.00467

15. Kosovo Agency of Statistics: International Trade Statistics, 2020, p. 13.

16. Kosovo Agency of Statistics: External Trade Statistics, 2020, p. 23.

17. Patnaik, S.: Emissions permit allocation and strategic firm behavior: Evidence from the oil sector in the European Union emissions trading scheme, Business Strategy and the Environment, 29 (3) 2020, p.976-995. https://ideas.repec.org/a/ bla/bstrat/v29y2020i3p976-995.html

- DOI: https://doi.org/10.1002/bse.2411

18. Qorraj, G.; Jusufi, G.: EU vs. Local Market Orientation: Western Balkan Entrepreneurs' Challenge, EBER- Entrepreneurial Business and Economics Review, 7 (4) 2019, p. 21-32.

- DOI: https://doi.org/10.15678/EBER.2019.070402

19. Qorraj, G.; Jusufi, G.: A. Survey conducted with firms exporting at EU: Comparison of characteristics between exporting firms and non-exporting firms in Kosovo in 2018.

20. Qorraj, G.; Jusufi, G.: B. Survey conducted with firms, non-exporters at EU market: Probit analysis of exporting firms and non-exporting firms in Kosovo in 2018. 
21. Qorraj, G.; Jusufi, G.: The EU Stabilization and Association Agreement for the Western Balkans: challenges and opportunities, Croatian International Relations Review 24 (81) 2018, p. 52.

- DOI: https://doi.org/10.2478/cirr-2018-0003

22. Raimondi, V. et al.: Trade effects of geographical indication policy: The EU case, Journal of Agricultural Economics, 71 (2) 2020, p. 330-356. https://ideas.repec. org/a/bla/jageco/v71y2020

- DOI: https://doi.org/10.1111/1477-9552.12349

23. Rose Malefane, M.: Trade openness and economic growth in Botswana: Evidence from cointegration and error-correction modeling, Cogent Economics \& Finance, 8 (1) 2020, p. 46. https://www.tandfonline.com/doi/pdf/10.1080/23322039.2020.1 783878 ?needAccess $=$ true

- DOI: https://doi.org/10.1080/23322039.2020.1783878

24. Roy-Mukherjee.; Sh., Udeogu, E.: Neo-liberal Globalization and Income Inequality: Panel Data Evidence from OECD and Western Balkan Countries, Journal of Balkan and Near Eastern Studies, 23 (1) 2021, p. 65.

- DOI: https://doi.org/10.1080/19448953.2020.1852004

25. Vo, T.T.; Nguyen, D.X.: Impact of Trade Liberalization on Household Welfare: An Analysis Using Household Exposure-to-Trade Indices, Social Indicators Research, 153, 2021, pp. 503-531. https://link.springer.com/article/10.1007/s11205020-02499-1\#citeas

- DOI: https://doi.org/10.1007/s11205-020-02499-1

26. Wagner, J.: Exports and Productivity: A Survey of the Evidence from Firm-level Data. World Economy, 30 (1) 2007, p. 60-82.

- DOI: https://doi.org/10.1111/j.1467-9701.2007.00872.x

27. Wagner, J.: Chapter 24: Export Scope and Characteristics of Destination Countries: Evidence from German Transaction Data, Micro econometric Studies of Firms' Imports and Exports, 2021, p. 445-451.

- DOI: https://doi.org/10.1142/9781786349699_0025 